Bartın Üniversitesi

Ceşm-i Cihan:

Tarih Kültür ve Sanat Araştırmaları E - Dergisi

ISSN: 2149-5866 Cilt:4, Sayı:2, s. 49-61, Kıș 2017

BARTIN - TÜRKIYE

\author{
Bartın ve Yöresi \\ Tarih - Kültür Araştırmaları \\ Uygulama ve Araştırma \\ Merkezi \\ (BAYTAM)
}

\title{
BASİT KÖMÜR KALEM YAPIMI VE YENİ BİR MEDYUM OLARAK ZOR SİLİNEN KÖMÜR KALEM
}

\author{
Yrd. Doç. Dr. Kerem İşCANOĞLU*
}

\begin{abstract}
Özet: Resim Sanatı pahalı bir sanat olarak görülebilir. Bunun en önemli sebebi sarf edilen malzemelerin nicel olarak çokluğu ve pahalı oluşudur. Türkiye gibi gelişmekte olan, ulusal sanatsal malzeme endüstrisi özellikle zayıf ülkelerde sorun daha fazla hissedilir. Öğrenci ve sanatçların maddi imkânları da burada önemlidir. Türkiye'de resim yapan sanatçı için finansman, önemli bir sorunsaldır. Bu doğrudan malzeme tedarikini zorlaştırmaktadır. Malzeme ve finansman sorunları giderilmeden resim sanatı üretimi istenilen noktalara ulaşamaz. Bunun için sanatçılara çeşit olarak fazla ve kolay malzeme üretme yöntemleri sunularak bu konuda katkı sağlanabilir. Burada araştırma amacımız, kömür kalem gibi yoğun kullanılan bir malzemenin sanatçılar tarafından kolay olarak yapılabilmesi ve bazı ek medyumlarla geliştirilerek daha efektif hale getirilmesidir. Bu konuda geleneksel bir malzeme olan kömür, kalem yapımının kolay olarak nasıl yapılabileceği konusunda bir deneme gerçekleştirilmiştir. Üretilen malzemenin eksik tarafı olan çabuk deformasyon noktasında bir çözüm geliştirilmeye çalışıldı. Üretimde geleneksel olanla yenisi denenerek sonuçlar karşılaştırıldı.
\end{abstract}

Anahtar Kelimeler: Klasik, Sanat, Malzeme, Kömür Kalem, Resim, Sanat.

\section{BASIC PRODUCTION OF CHARCOAL AND AS A NEW MEDIUM DURABLE CHARCOAL PRODUCTION}

\begin{abstract}
Painting can be seen as an expensive method of art. The most important reason for this is the quantitative multiplicity and costly amount of materials consumed. Developing countries such as Turkey, the national artistic material industry is particularly vulnerable in weaker countries. The material possibilities of students and artists are also important here. The biggest problems of the artist in Turkey are the financing problems. This makes direct material supply difficult. The production of art of painting can not reach desired points without solving the problems of material and financing. To this end, it is possible to contribute to this issue by presenting more and more easy methods of producing materials to artists. This is basically the exit point. The aim of our research here is to make it easier for artists to use an intensive material such as coal pencil and to make it more effective by developing with some additional media. In this regard, a trial was made on how to make coal mine which is a traditional material easily. It was tried to develop a solution in the point of being a quick deformation which is the incomplete side of the produced material. The results were compared comparing the traditional one produced and the new one.
\end{abstract}

Keywords: Classical, Art, Material, Charcoal, Painting, Art.

\section{Giriş}

Resim sanatının en önemli gereçlerinden birisi kömür kalemdir. Füzen, kömür gibi adlarla da anılabilir. Dallardan yapılan kalemler gibi kömür tozlarının sıkıştırılmasıyla da elde edilen türleri vardır. "Ressamlarca büyük bir zevkle kullanılan füzen en eski ve en basit, fakat çok değerli bir desen malzemesidir." (Bigalı, 1984, s.228) Eski dönemlerden beri pratik olarak üretilebilmesi ve etkisindeki eşsizlik onun neredeyse her dönem etkin olarak kullanılagelmesini

\footnotetext{
* Trakya Üniversitesi, Güzel Sanatlar Fakültesi
} 
sağlamıştır. Günümüzde kömür kalem en çok tüketilen sanat gereçlerinden biridir. Tarih öncesi duvar resimlerinde kayalara yapılan çizimlerden başlayarak günümüze kadar kullanıldığı düşünüldüğünde kömür kalemin en eski resim malzemelerinden biri olduğu anlaşılabilir. Kathe Kollwitz'den Degas'a veya Rönesans üstatlarına eşsiz denilebilecek özelliklleri ve kullanım pratiğiyle kömür kalemin her zaman popüler bir malzeme olduğu da burada söylenmelidir. Çizim resim sanatının hep merkezinde yer aldı ve tabi ki kömür kalem de." denildiği gibi, çizgiyle başlanır." (Finlay, 2002,s.76).

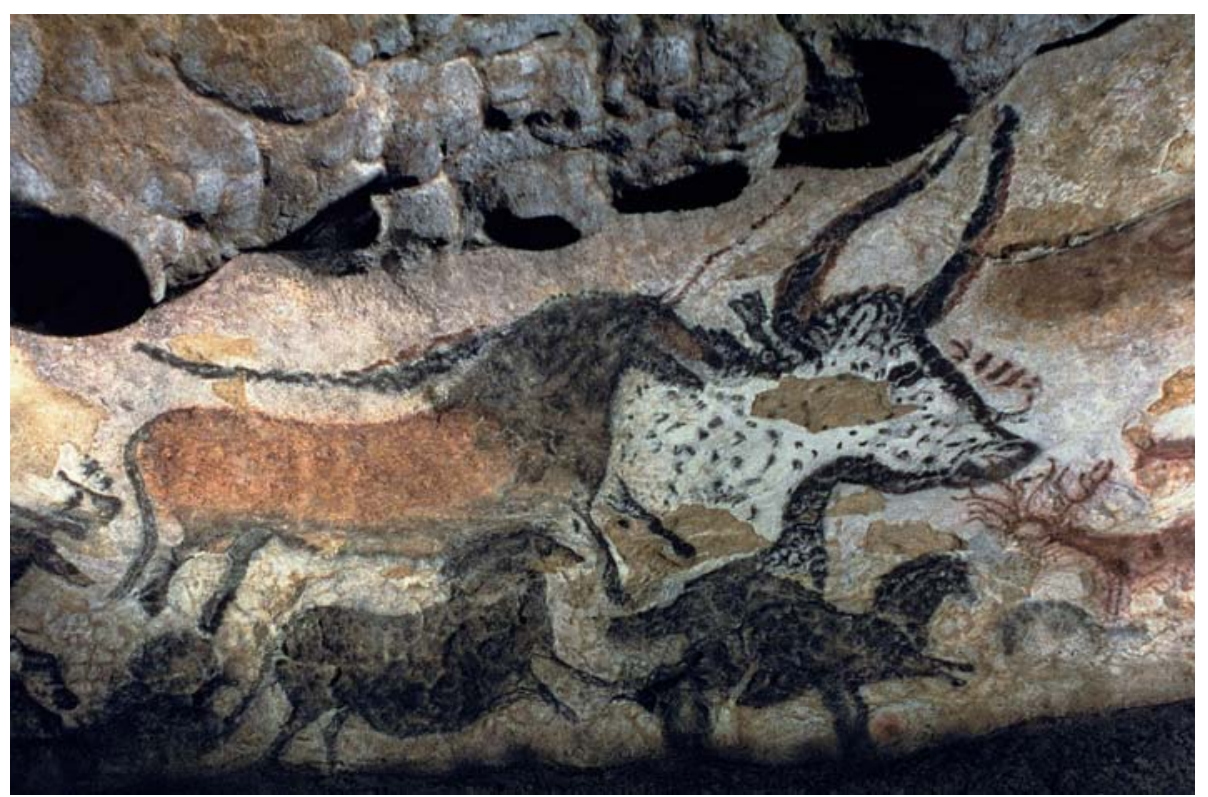

Görsel 1: Taşdevri mağara resmindeki kömür kalem kullanımı örneği

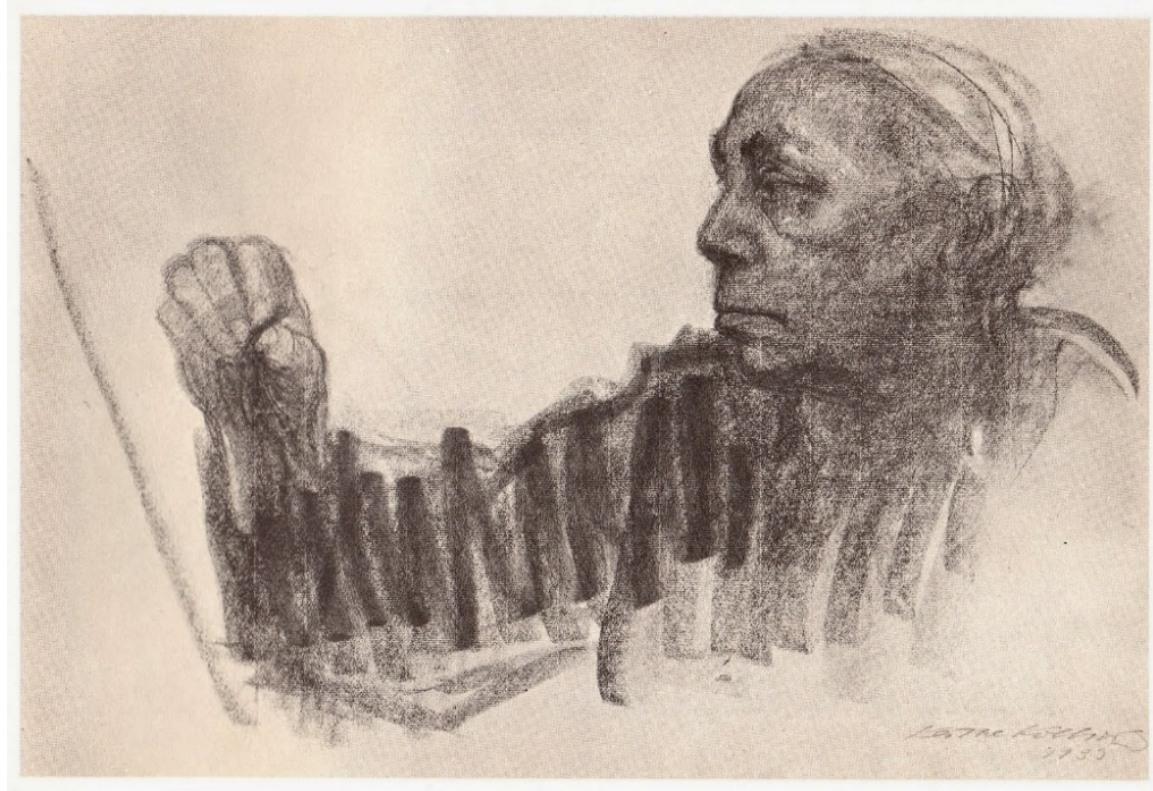

Görsel2: Kathe Kollwitz’in kömür kalemle yapılmış bir otoportresi. 
Resim sanatının gelişiminde ve sanat akımlarının oluşumunda yeni bilgilerin ve malzemelerinin icadının yaptığı katkıları da burada hatırlamak gerekir. Bu icatların makalemizle ilgili kısmı olan yeni malzemelerdir. Bugün açık havada resim yapma geleneğinden bahsedebiliyorsak bu bir oranda keşfedilen kutu içerisinde kullanışlı suluboya veya tüp şeklinde ve taşınabilir yağlıboyanın üretilmesiyle doğrudan bağlantılıdır. "1300’lerin sonlarında Cennino, örneğin bir kadife cüppe resminin üst tabakasını boyarken yağ kullanmıştı." (Finlay,2002, s.31) Yağlıboyanın bulunuşu da resim sanatını doğrudan etkilemiştir. Yeni tekniklerle yeni sanat formları ve düşüncelerin doğrudan ilişkili olduğunu söyleyebiliriz. Bu araştırmanın yapılmasını anlamlı kılan bir neden de budur. Yeni malzemeler geliştirebilirse, yeni tekniklerin gelişimini kolaylaştırılabilir. Bir diğeri neden de, resim sanatının bol malzeme sarf eden, tüketime dayalı niteliğinin onun üretimini zorlaştırmasıdır. Sanatçıların hayatlarını kolaylaştırıcı bilgileri özümsemesi anlamlıdır. Okullarda verilen resim teknolojisi dersi bu konuda katkı sağlamaktadır. Ancak büyük fotoğrafta bilgiyi yaygınlaştırmak önemli görülmelidir. Ülkemiz açısından da sanata yapılan finansmanın yeterli olmaması üretim devamlılığını ciddi olarak aksatmaktadır. Bilgiyi paylaşarak yaygınlaştırmak gelişim için büyük önem arz eder.

Ülkemizde sanata yapılan finansmanın yeterli olmaması üretim devamlılığını ciddi olarak aksatmaktadır. Bu da başka bir problemi işaret etmektedir. Öğrenciler, serbest ressamlar dar bütçeleri ile mücadele etmekte ve sonuçta işlerinin kalitelerinde ciddi aksamalar olabilmektedir. Çok üretim, çok tüketmek demektir ve doğru sonuçlara ulaşmanın yolları sanat pratiğinin arttırılmasından geçer. Bu konu bizler için daha kritiktir. Ülkemizin sanat ortamı istenen noktaya gelmekten epeyce uzaktır ve sanata verilen destek belli isimler üzerine yoğunlaşmakta, sanatçılar yoğun maddi zorluklarla karşı karşıya kalmaktadır. Ali Akay Türk sanatçısının dünya merkezleri ile kıyaslandığında maddi olarak durumunu şu şekilde özetler:

“...bugünde sanatlarda baktığımız zaman Batı toplumlarında, özellikle İngiltere sanatçısına veya orada oturan sanatçılara büyük bir destek olduğu çok kuvvetli bir şekilde gözüküyor. O sanatçıların bu destekten faydalandıkları gözüküyor. Dünya piyasasında bu sanatçıların isimlerinden ve eserlerinden söz ettiğimizde, bunların çok yüksek bir şekilde değer kazandığı görülürken, Türkiye'den veya Balkanlar'dan ya da eski anlamıyla Üçüncü Dünya diyebileceğimiz yerlerden gelen sanatçlların yaptıkları- üretimlerinin kalitelerinden bahsetmiyorum, parasal değerlerinden bahsediyorum-neredeyse bedava değerine sahipler..." (Sanat Dünyamız, Ali Akay, 2006, 63-64)

Ülkemizin bu hususta yaşadığı sıkıntılar birisi de kullanılan ürünlerin çoğunlukla ithal olmasıdır. Yerli sanat malzemelerinin ithal malzemeler karşısında oranı istenen düzeyde değildir. Üniversitelerimize ve bilim adamlarımıza düşen görevlerden biri de yerli üretimin desteklenmesidir. Sektörde faaliyet gösteren firmalarla bilgi paylaşımı işin sorunsalı 
düzeltmenin bir ayağını oluşturmaktadır. Diğeri ise sanatçıların kendi malzemelerini yapabilmesi için pratik yöntemlerin üretilmesi ve onlara sunulmasıdır. Bu özellikle sanatın finansmanında yaşanılan sorunların üretimi etkilememesi için pozitif etki yapabilir.

Ressamın özgürlüğü nesnel olarak malzemelerinin sınırları içerisinde şekillenir. Eğer sanatçı buna sahipse özgürlük alanı genişler. Malzeme tüketimine bağlı çalışmalar üreten sanatçllar malzemelerinin elde edebildikleri oranda özgürdürler. Özgürlükse sanatın temel dinamiklerindendir. Andre Lothe sanatçının bağımsız olmasının gerekliliğini başka bir açıdan şu sözlerle değerlendirmektedir:

“Öte yandan burada, iyilikbilmez bir tutuma da açılılık getirmek gerekiyor. Her şey bir yana, sanatta "bağımsız" olmanın gerekliliği su götürmez. İnce bir dille söylemek gerekirse, birkaç yıldır, Cezanne'ın kişiliğinde özgürleștirici bir kimlik ve ... Cezanne bugün her zamankinden daha önemli bir sanatçı kişiliği vurgulamaktadır." (Lhote, 2000, s.46)

Cezanne'ın bağımsız kişiliği onun sanatçılığının önemli değerlerindendir. Özgün dilin kuruluşunun ve bağımsızlık kavramlarının malzeme araştırmalarıyla veya bol malzemeyle doğrudan bağlantısı vardır.

Bir diğer önemli konu ise klasik malzemelerin geliştirilmesidir. Geleneksel malzemelerin ilerletilmesi ve onlarla yaşanılan sorunların giderilmesi kullanımlarının arttırılması için gereklidir. Bunun için çeşitli denemeler gerçekleştirilmiş ve bulgular konusunda notlar alınmıștır. Kömür kalemle ilgili yașanan en büyük sorunlardan biri olan kolayca silinme veya tahrip olabilme ihtimaline karşı bir çözüm üretme denemesi yapılmış ve uygulamanın aşamaları görüntülerle kayıt altına alınmıştır.

\section{Uygulama}

Öncelikle büyük olmaması gereken bir teneke kutu bulunur. Teneke kutunun hacmi ile ateşin boyutu arasında oran uygunluğu burada en önemli etkendir. 10 litrelik yağ tenekelerinin kömür kalem yapımında kullanımı yapılan denemelerin sonucu verimli olmamıştır. Bunun sebebi kutu içerisindeki hacmin her noktasında ısının eşit dağılımında yaşanan sıkıntıdır. Bunun için ateşle kömür yapımında kabın küçük olması ısının eşit dağılımına katkı sağlar. Bu açıdan beş ve bir litrelik hacimlerde istenilen sonucu almanın daha kolay olduğu görülmüştür.

Uygun olarak bulabileceğimiz herhangi bir teneke kutu alınır. Kutunun kapaklı olması istenilen sonucun alınmasında daha ileride göreceğimiz bir kolaylığa sebep olur(Alüminyum folyo ile kutuyu kapatmak sağlıklı olmayabilir). Sonrasında kömür kalem yapımı için doğadan kolayca bulabileceğimiz dallar toplanır. Bu dalların genel olarak söğüt dalı veya bağ çubuğu olması konusunda ilgili kaynaklarda çeşitli notlara rastlanmaktadır. Mesut Erdem kömür kalem yapma işleminde söğüt ağacının kullanılmasını tavsiye etmiş ve füzenin kömür kalem yapımında kullanılan bir ağacın olduğu ve oradan malzeme için kullanılan ismin de oradan geldiğini 
belirtmiş̧tir (Erdem, 2005, s.34). Fakat yaptığım denemeler bu konuda bahsi geçen iki ağacın dışında diğer ağaçlarla da benzer etkilerin oluşturulabildiğini görmemi sağladı. Bu açıdan geniş yapraklı ağaçların genç dalları seçebilir.

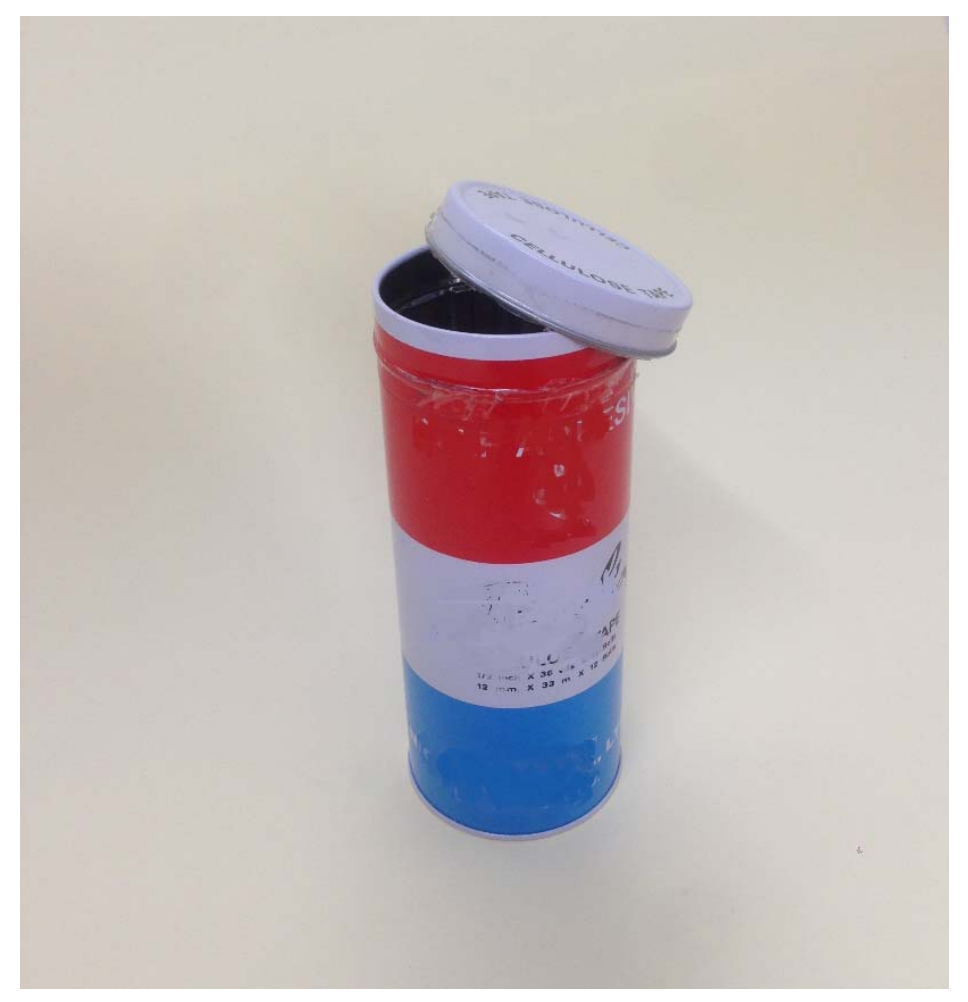

Görsel 3: Kömür yapımında kullanılabilecek bir artık kutu.

Kömür kalem yapımındaki diğer bir konu ise kömür yapımında kullanılan dalların kabuklarının olmamasıdır. Bu, kömürleşmeden sonra sert bir yüzey oluşturması nedeniyle çizimi olumsuz etkilemektedir. Bunun için kömür kalem yapımında kullanılacak dalların veya ahşapların kabuksuz olması gerekmektedir. (Bunun bazı ağaçlarda sıkıntı yaratmadığı da söylenebilir. Kişinin kendi deneyimleri burada belirleyicidir).

Öncelikle dallar veya kavak gibi sert olmayan ağaçlardan alınan dallar ince çıtalar halinde kesilir. Meşe gibi sert ağaçlar dışındaki nispeten yumuşak ağaçlar kullanılabilir. Bunun sebebi sert ağaçların kalemlerinin de sert olacak olmasıdır. Kalemdeki sertlik çizimi olumsuz etkiler. Söğüt ağacının dalları çok olumlu sonuçlar vermektedir. Farklı ağaçlardan farklı tatlarda çizgiler alınabilir bu açıdan farklı ağaçların kullanılması zengin değer için bir yöntem olarak kullanılabilir. 

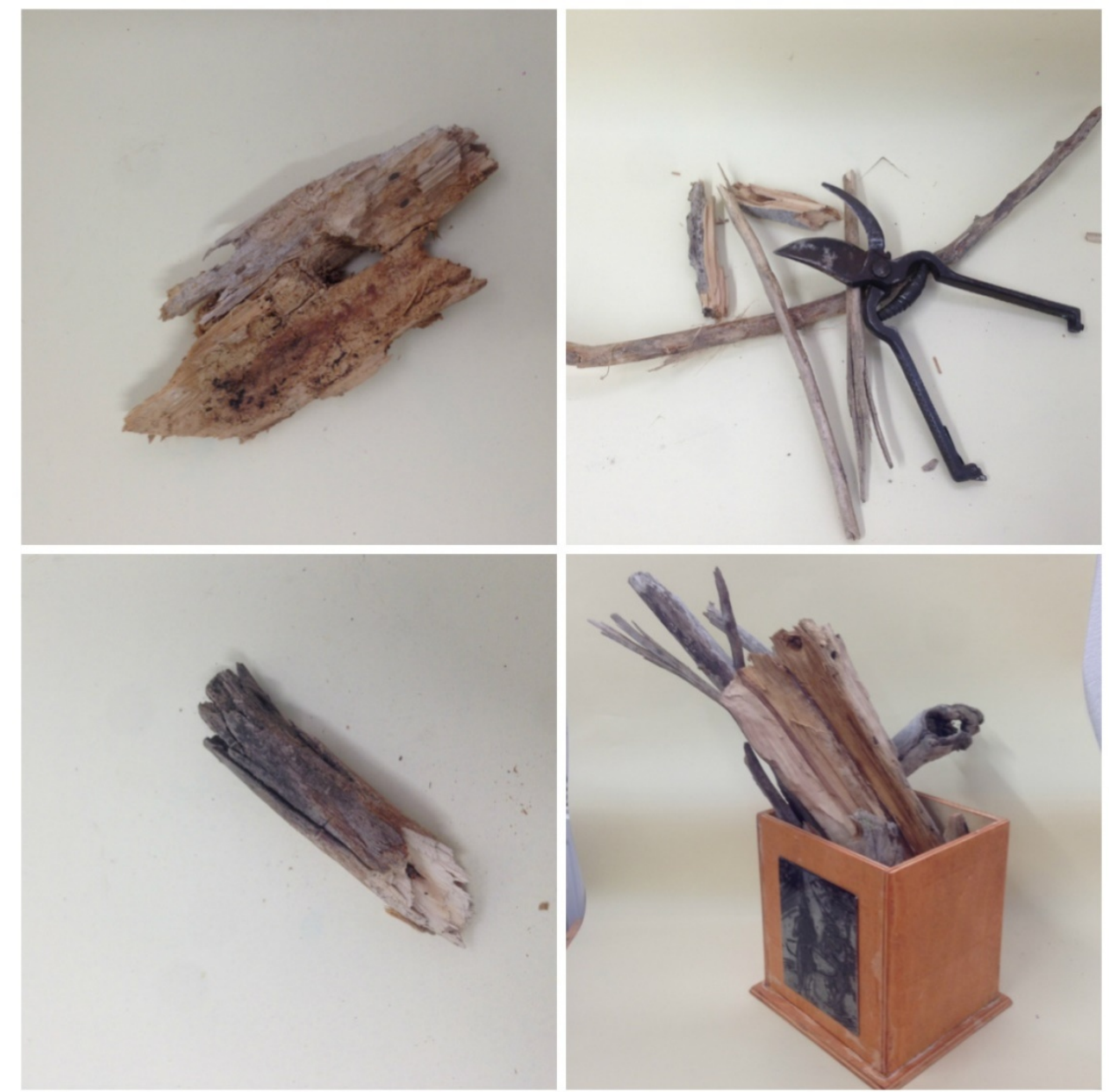

Görsel 4: Kömür yapımında kullanılmak üzere toplanılan bağ makası ve dallar.

Bulduğumuz dal parçalarını kesme makasımızla kutumuz ölçüsünde keseriz. Kesimi tamamladıktan sonra sıkışık olarak asgari hava boşluğu bırakarak kutumuzun içerisine dallarımızı yerleştiririz. Üstte kalan boşluk olursa onu da küçük dal parçalarıyla doldurularak daha az boşluğun kalmasını sağlarız. 


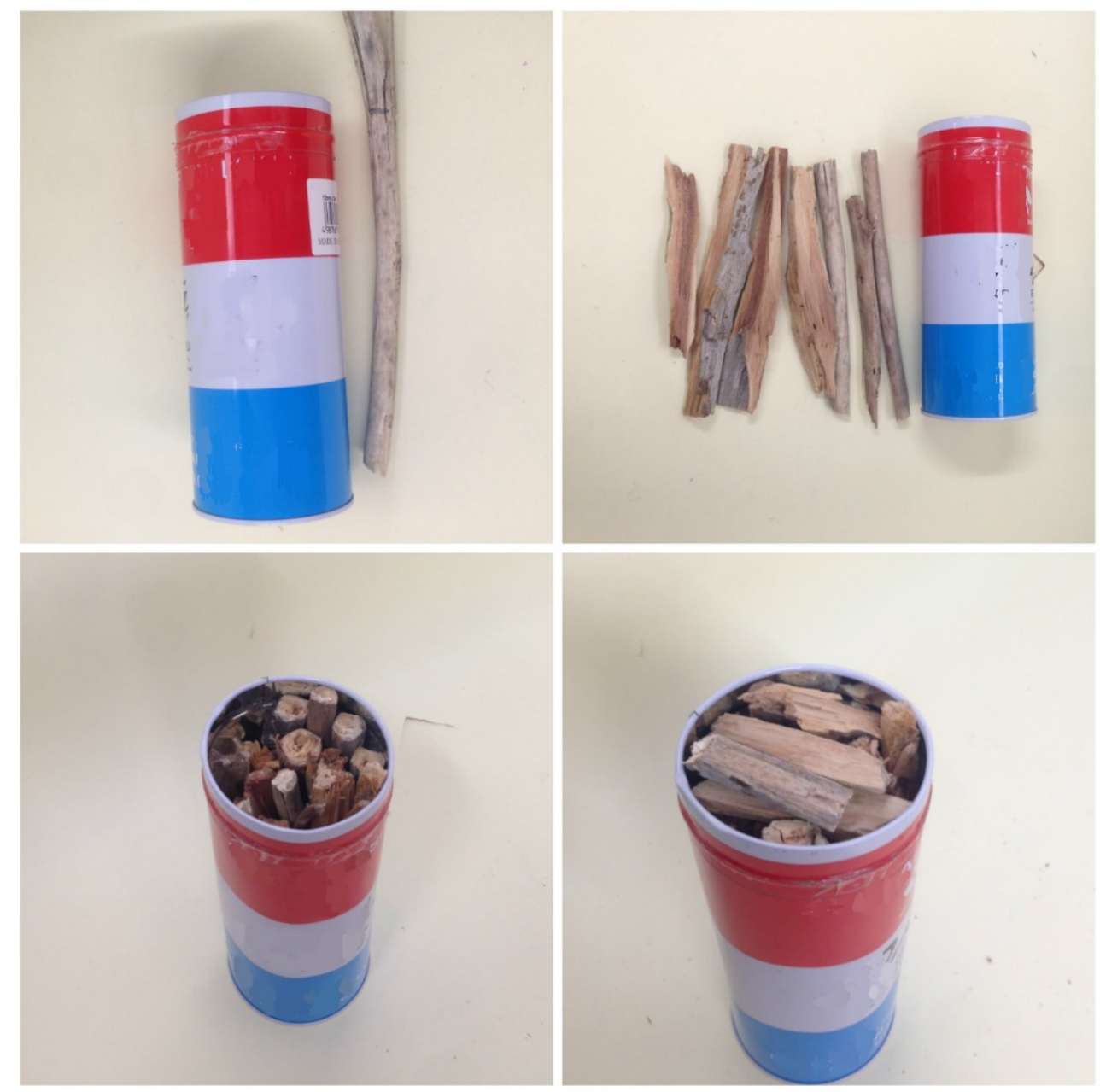

Görsel 5: Kömür yapımında kullanılmak üzere toplanılan dalların belli boyutlarda kesilmesi ve sıkışık olarak kutunun içerisine yerleştirilmesi.

Kapağın kapatılmasından sonra matkap veya daha pratik bulunan başka bir yöntemle (çivide kullanılabilir) kapakla alt bölümün kesişme yerlerine karşılıklı olarak iki delik ve üste de bir veya daha fazla küçük delik delinir. Deliklerin sebebi gaz çıkışının belli oranlarda da olsa sağlanmasıdır. Kesişme yerleri dediğimiz deliklere birer vida takılır. Bunun sebebi kapağın içeriden gaz çıkışının artması ve yanan boya ile kapağının çıkıp hava alımının artması tehlikesidir. Kapağın düşmesi durumunda kömür alınamaz ve dallar tamamen yanar. Bu konuda tornavida veya vidalama aleti ya da sadece deliklere birer çivi sokulmasıyla kapak tutturulur. Vida başlarına ateşten kutunun rahatça çekilebilmesi için demir, bakır gibi ısıya dayanıklı tel takılır (alüminyum gibi metallerin ısı dayanımlarının düşük olduğu unutulmamalıdır). Bu tel sayesinde rahatça ateşin içerisinden kutumuzu alabiliriz. 

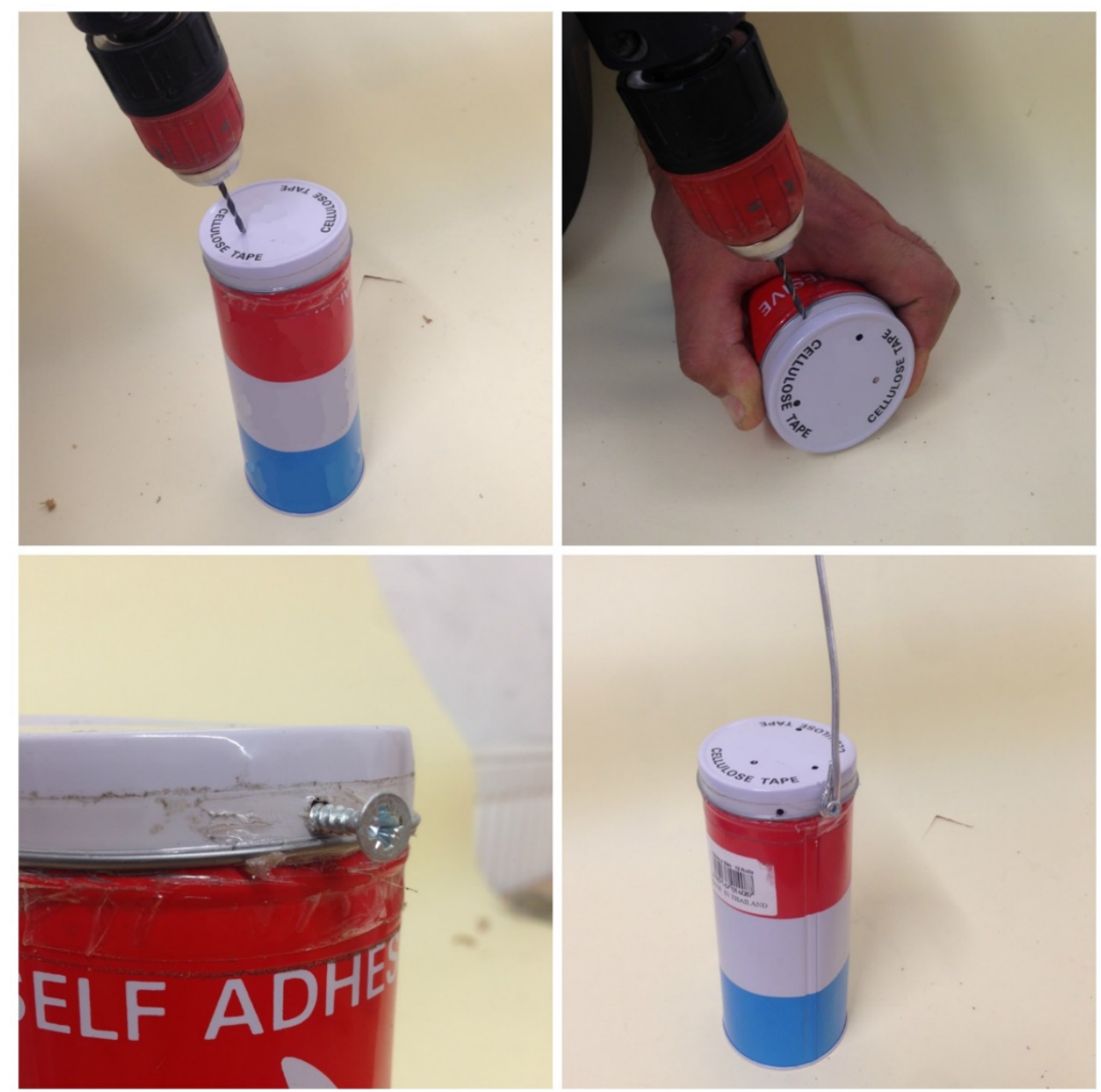

Görsel 6: Kutunun kapağının kapatılması, gaz çıkışı ve kapağın yerinde tutulması için gerekli deliklerin açılması, iki yana olmak üzere vidaların takılması ve ateşte kontrol için tutma telinin takılması.

$\mathrm{Bu}$ işlemin sonunda ısıl işleme geçilir. Öncelikle soba, herhangi bir kabın içerisinde veya uygun bulunan bir yerde ateş çeşitli çalı çırpı parçalarıyla yakılır. Ateşin içerisine tel yardımıyla teneke kutumuzu koyarız. Üzerinden ateşi beslemeye devam ederiz. Isının kutunun bütününe eşit olarak dağılım yapmasını sağlamak buradaki önemli noktadır. Buna dikkat edilerek süreç izlenir. Kutudan kısa bir süre sonra koyu renkli bir gaz çıkmaya başlayacaktır gazın çıkışı artacak ve sonunda azalarak tamamıyla koyu gaz çıkışı noktalanacaktır. Bu durum kömürümüzün olduğuna işarettir. Kutumuzu ateşten çekerek havayla tamamen bağını keserek soğuması beklenir. Kuma gömmek bir yöntem olarak değerlendirilebilir. Artık kömürümüz kullanıma hazırdır. Herhangi bir kâğıt üzerinde deneyerek çıkan sonucu değerlendirebiliriz. 
BASİT KÖMÜR KALEM YAPIMI VE YENİ BİR MEDYUM OLARAK ZOR SİLINEN KÖMÜR KALEM Yrd. Doç. Dr. Kerem İŞCANOĞLU
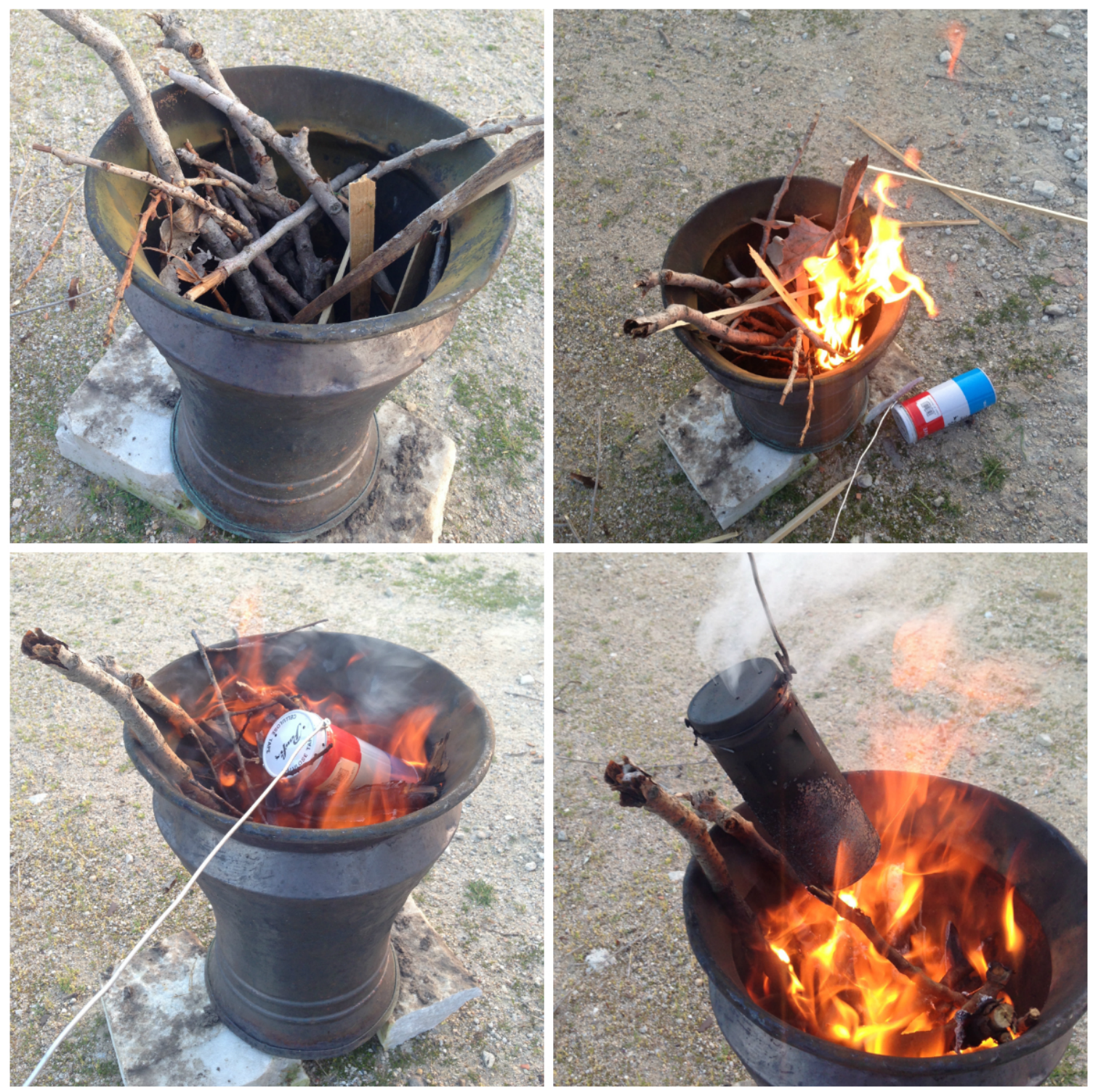

Görsel 7: Ateş yakacak yerin ve dalların hazırlanması, ateşin yakılması, ateşe tel yardımıyla tenekenin yerleştirilmesi, ara ara tenekedeki gaz çıkışların gözlenmesi. 

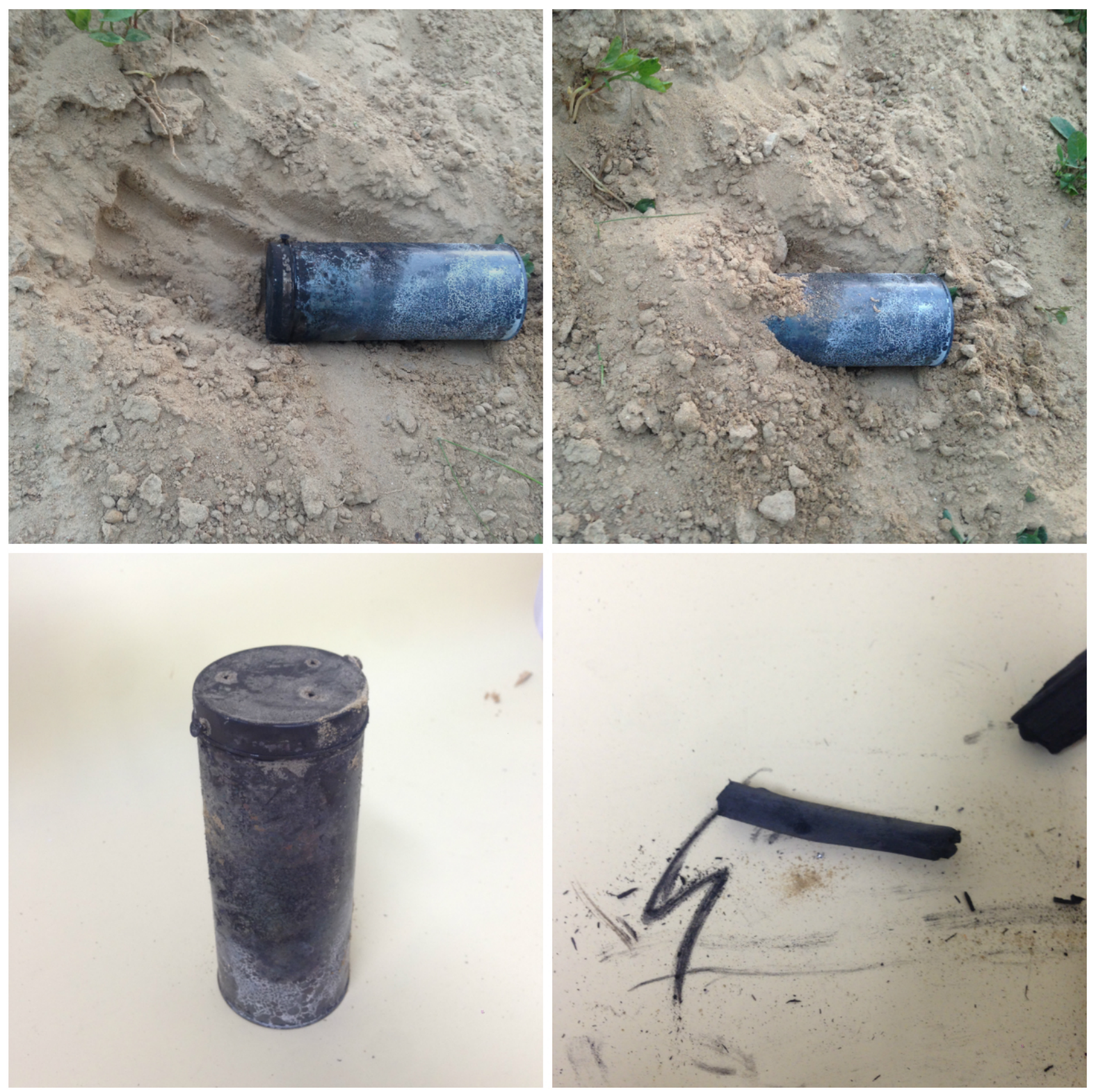

Görsel 8: Tenekeden koyu renkli gaz çıkışının bitmesiyle beraber deliklerden hava almaması için ağzının toprakla örtülmesi ve soğumayla beraber kalemlerin kullanıma hazır hale gelmesi.

\section{Yenilik}

Buraya kadar kömür kalem yapımının büyük oranda bilinen bütün evrelerini bir biçimde tekrarlanmıştır. Kalem izlerinin rahat silinebilmesi avantaj olarak görülebilir veya çoğu sanatçı geleneksel malzemelere müdahale etmeyi hoş karşlamayabilir fakat "seyirci ve sanatseverler için, önemli olan nokta neticedir”. Kömür kalemin en aksayan tarafı kağıt uygulamalarında kalıcılık için başka gereçlere duyulan ihtiyaçtır. Bu kömür kalemin kullanımını azaltan en önemli faktördür. Fixatifler bu iş için sıklıkla kullanılır; bunlar, ilave masraf demektir. Ama ben burada daha kalıcı bir kömür kalem yapmak için başka bir yöntemi öneriyoruz. Bu bir bakıma silinmez 
veya zor silinen kömür kalemin yapımıdır. Burada önerilen formül belli oranlarda keten veya benzeri yağlarla, terebentini veya tiner gibi çözücü yağların karışımından oluşan çözeltiler oluşturmak ve kömürümüzü bunda bekletmektir. Denemelerimde üçte bir oranında terebentine keten yağını karıștırarak onun içerisinde yaptığımız kömürü beklettim ve sonucunda standart kömür kalemden çok daha kalıcı olan kömür kalem elde ettim. Burada temel olarak yapılacak işlem pet bir şişenin kesilmesi ve içerisine bir ölçek terebentin ve üç ölçek keten yağının katıldığı çözeltinin oluşturulmasıdır. Sonrasında yaptığımız kömür kalemlerini bir süre bu sıvı içerisinde bekletiriz. Bir süre sonra kömürlerin yüzeyden çöktüğü gözlemlenecektir. Bu sıvının kömürler tarafından emildiğini göstermektedir. Sonrasında malzememiz kullanılabilir.
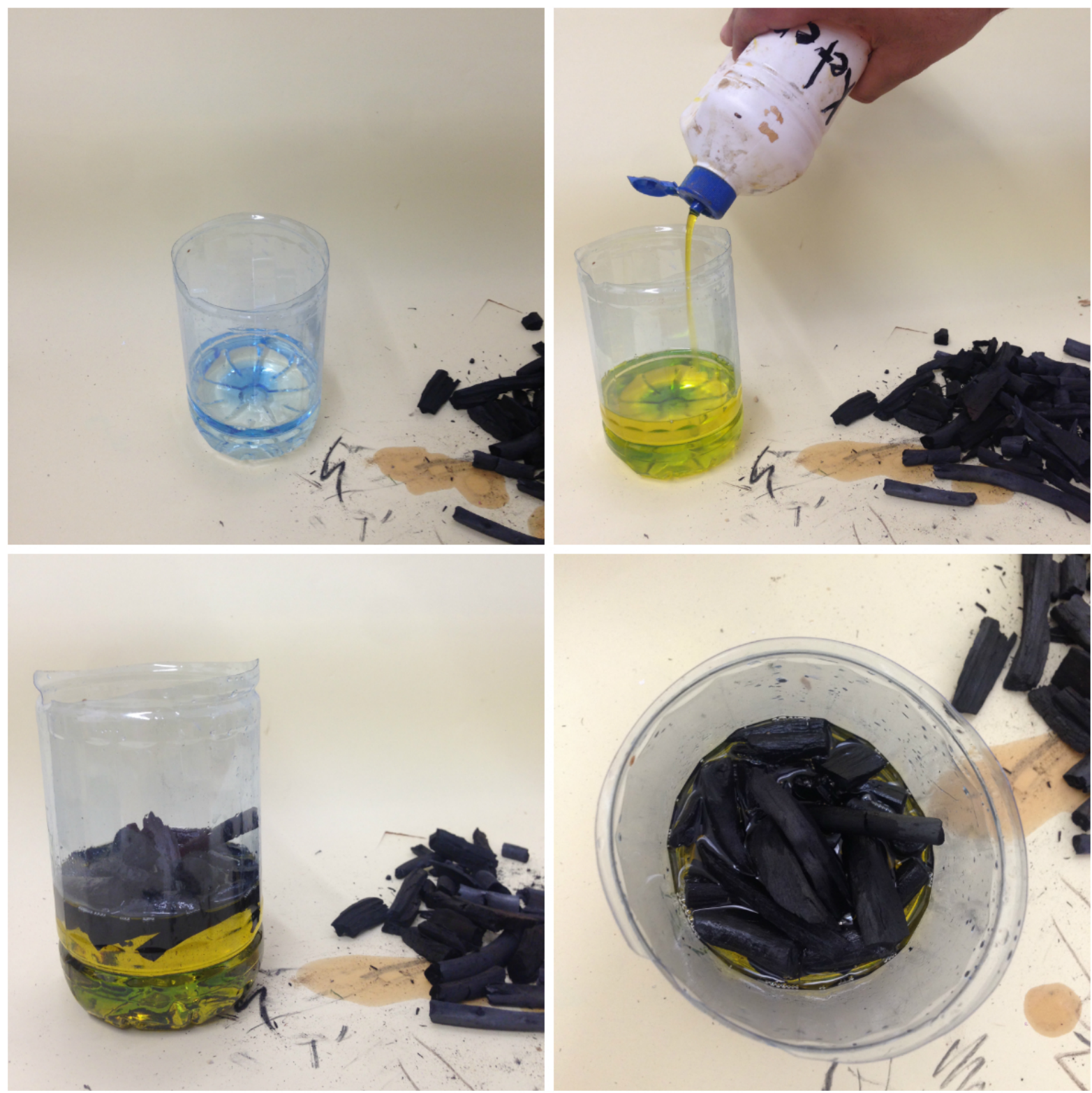

Görsel 9: Yapılan kömür kalemlerin yağ ve terebentin karışımına atılarak bir süre beklenmesi. 
Son olarak yaptığımız malzemenin denenmesi ve sorun olarak çözümlemeye çalıştığımız kalıcılık konusunun sınanması vardır. Kâğıda yağlı karışımda bekletilen ve bekletilmeyen iki malzeme sürüldü ve parmakla dağıtılmaya çalışıldı çıkan sonuç çözeltinin işe yaradığını bizlere göstermektedir.
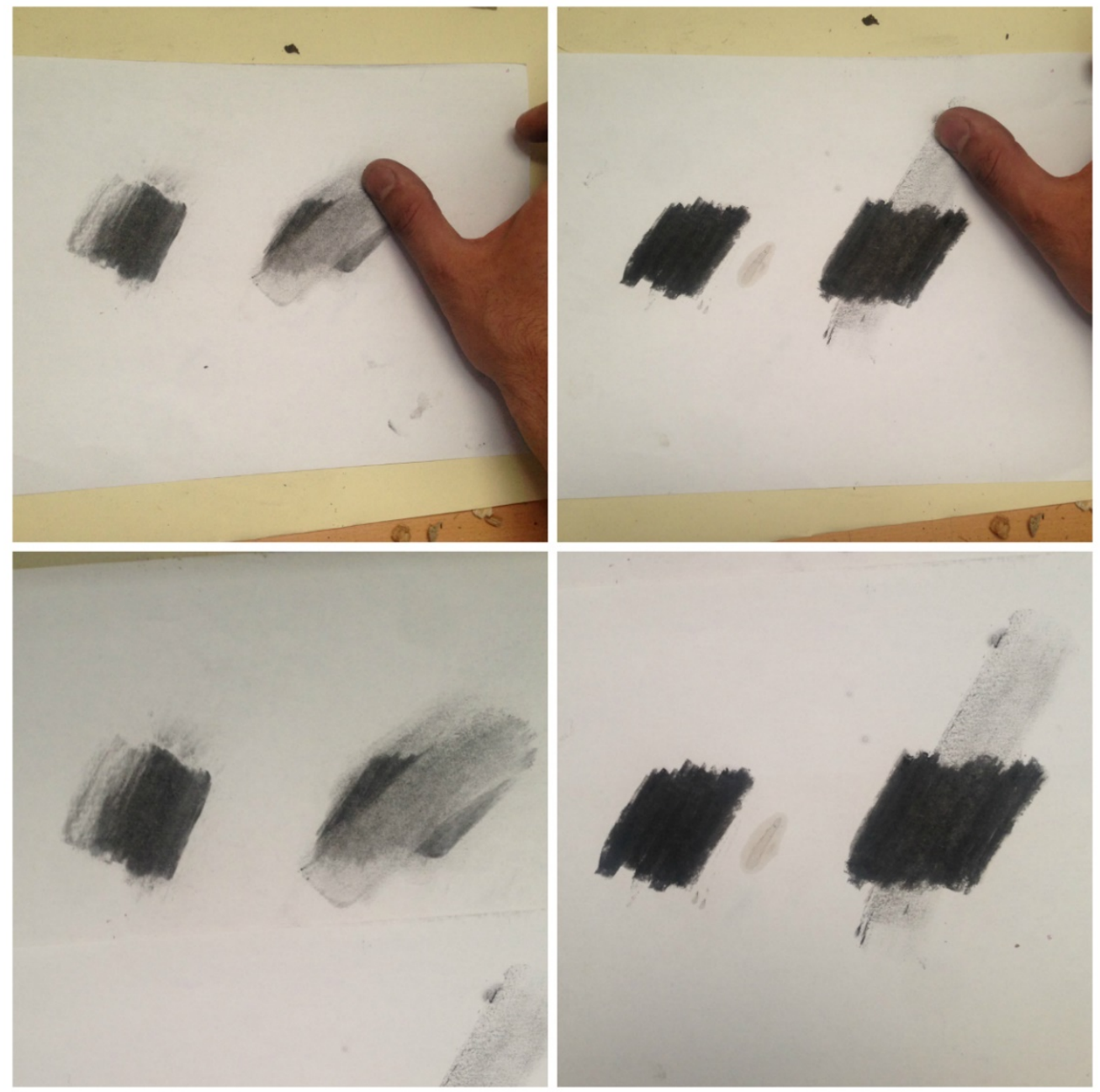

Görsel 10: Karışımda bekletilmeyen (soldaki örnek) ve bekletilen kömür kalemlerin denenmesi. Parmakla yapılan işlemle kalıcılı̆̆ın ölçülmesi.

\section{Sonuç}

Temelde bu yazıda resim sanatında yoğunlukla kullanılan kömür kalemin nasıl yapılabileceği konusunda bilgi üretilmeye çalışıldı. Üretim süreçleri görsel ve yazılı olarak kaydedilmiştir. Yazıyı okuma fırsatı bulan okur içerisinde bulunduran görsel malzeme ile kendisinin de aynı süreci tekrar üretebilmesi hedeflenmiştir. Sanat malzemelerine birçok şehrimizde ulaşma şansına sahip olmadığımız, bulunabilenlerin pahalı olduğu gerçeği ile karşı karşıya olduğumuz ve teknik ilerlemelerin resim sanatında doğrudan ilerletici rolü olduğu ve ülkemizin yerli sanat endüstrisinde zayıf olduğu noktasından hareket edilmiştir. Basit olarak kömür kalem üretilmesi için bir uygulama örneği üretildi ve kömür kalemin aksayan tarafı olan 
bozulmaya karşı olan dayanıksızlığı noktasında da dair çözüm önerisi geliştirilmiştir. Yapılan uygulamanın sonucunda zor silinen ve kullanılması için fixatif gibi ek bir malzemeye ihtiyaç duyulmayan bir ürüne ulaşılmıştır. Yapılan denemeler ve karşılaştırmalar sonucunda, üretilen ürünün istenilen çözümü sağladığı görülmüștür. Yeni malzemelerin üretilmesi, daha fazla malzeme hakkında pratik bilgiler üretmek ve yapılışları hakkında çeşitli bilgiler vermek sanatçının özgürlük alanını ve malzemelerin kimyasına karşı duyarlılı̆̆ını artırabilir. Bu konuda yapılacak çalışmalar sayesinde yerli üretimin gelişimi ilgili patentlerinde alınmasıyla sağlanabilir ve ülke ekonomisine katkı sunulabilir. Bu çalışmaların devam ederek kuru kalem yağlıboya gibi medyumlar üzerinde denemelerin gerçekleştirilerek yeni medyumların üretilmesinin gerekli olduğu kanaatimiz güçlenmiştir. Bu açıdan istenen başarının kaydedilmiş olması bu çalışmalara devam edilmesinin önemli olduğu kanaatine varılmasını sağlamıştır.

\section{KAYNAKÇA}

Bigalı, Ș. “Resim Sanatı”, 1984, İrfan Klişe Reprodüksiyon

Cerver, F. A. "Yeni Başlayanlar İçin Pastel” (Çeviri: Süreyya Evren Türkeli) , 2005, Literatür Yayıncilik

Erdem, M. "Resim Tekniği”, 2005, Arkeoloji ve Sanat Yayınları

Finlay, V. “Boya kutusuna Yolculuklar, Renkler”(Çeviri: Kudret Emiroğlu),2002, Dost Yayınları

Lhote, A. “Sanatta Değișmeyen Plastik Değerler” (Çeviri: Kaya Özsezgin), 2000, İmge Kitabevi

Parramon, J. M. “Çizim ve Resim Sanatı” (Çeviri: Gönül Sipahi Çapan), 1999, Remzi Kitabevi

"Sanat Dünyamız Dergisi”, sayı:98, Bahar 2006, Yapı Kredi Yayınları.

https://books.google.com.tr/books?id=KRtRIFbEPIQC\&printsec=frontcover\&dq=charcoal\&hl=

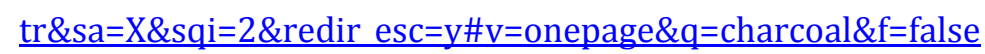

https://books.google.com.tr/books?id=WwhfFDy1WYC\&pg=PA28\&dq=charcoal\&hl=tr\&sa=X\&ved=0ahUKEwiYZKJ3bfUAhXMtRQKHXqmCicQ6AEIWzAH\#v=onepage $\& q=$ charcoal $\& \mathrm{f}=$ false

\section{Görüntü Kaynakçası:}

Görüntü 1: https://s-media-cacheak0.pinimg.com/originals/20/ae/4d/20ae4d3c13e7e5586bc1f926c446ad19.jpg Erişim Tarihi: 09.06.2017

Görüntü2: http://3.bp.blogspot.com/sKe3m01RZT8/VCLVKgGrxcI/AAAAAAAAd74/SdWR1kvZIUo/s1600/kollwitz\%2Bselfportrait\%2Bat\%2Bwork.jpg Erişim Tarihi: 09.06.2017 